\title{
Effect of the Aqueous Extract of Neem Leaves (Azadirachta indica A. Juss.) on the Control of Costalimaita ferruginea (Fabricius, 1801)
}

\author{
Roldão Carlos Andrade Limaa ${ }^{1 *}$, Mauricélia Ferreira Almeida ${ }^{2}$, \\ Adriana de Sousa Freitas ${ }^{2}$, Andressa Layane Ferreira Linhares ${ }^{3}$, \\ Bianca Pinheiro da Costa Neiva ${ }^{2}$, Brunna Tavares da Silva Brito Sousa ${ }^{4}$, \\ Jeferson Pereira da Silva ${ }^{2}$, Kaio Lucena Vidal ${ }^{3}$, Felipe Ferreira da Silva ${ }^{5}$, \\ Gabriel Alves Santos ${ }^{2}$ and Raylson Marcelo Fernandes de Lima ${ }^{6}$
}

${ }^{1}$ Faculty of Agronomic Sciences, São Paulo State University "Júlio De Mesquita Filho", Brazil. ${ }^{2}$ Center for Agrarian Sciences, State University of the Tocantina Region of Maranhão, Brazil.

${ }^{3}$ Institute of Agricultural Sciences, Federal University of Minas Gerais, Brazil.

${ }^{4}$ Gurupi University Campus, Federal University of Tocantins, Brazil.

${ }^{5}$ Center for Agricultural Sciences and Engineering, Federal University of Espírito Santo, Brazil.

${ }^{6}$ Faculty of Medical Sciences, Holy House of São Paulo, Brazil.

Authors' contributions

This work was carried out in collaboration among all authors. The authors RCAL and MFA designed the study, performed the statistical analysis and wrote the first draft of the manuscript. The authors ASF, FFS and GAS collected the specimens in the field. The authors ALFL, BTSBS, BPCN, JPS and $K L V$ performed the laboratory experiments. The author RMFL managed the bibliographic searches. All authors read and approved the final manuscript.

Article Information

DOI: $10.9734 / A R R B / 2021 / v 36 i 930421$

(1) Prof. Ibrahim Farah, Jackson State University, USA. Reviewers:

(1) Mihammed Ali Makki, Wasit university .Iraq. (2) Ruqaya mohammed Ibrahim, Al-Nahrain university, Iraq. Complete Peer review History: https://www.sdiarticle4.com/review-history/72571

Original Research Article

Received 22 June 2021

Accepted 31 August 2021 Published 03 September 2021

\section{ABSTRACT}

Aims: Evaluate the insecticidal effect of the aqueous extract of neem leaves on the control of Costalimaita ferruginea in eucalyptus.

Place and Duration of Study: Entomology Laboratory of the Center for Agricultural Sciences 
(CCA) of the State University of the Tocantina Region of Maranhão (UEMASUL) between November 2016 and July 2017.

Methodology: Neem aqueous extract solutions were tested at concentrations of 40,60 and $80 \%$, and the control group treated with mineral water. Leaves of eucalyptus seedlings were immersed in each concentration and individualized in Petri dishes together with the insects. The design was completely randomized with four treatments and ten repetitions, each repetition consisting of a Petri dish with an insect and a eucalyptus leaf. The evaluations were carried out daily, analyzing the mortality of adults, and the leaves were replaced by others submitted to the same treatment and procedure described above. Results: In the evaluations of 12, 60, 72 and 84 hours there was no significant difference. 36 hours after the implementation of the experiment, the $60 \%$ neem concentration resulted in $100 \%$ mortality of specimens.

Conclusion: The $60 \%$ neem concentration is the most efficient due to its rapid effect on $C$. ferruginea mortality and economy of raw material for production.

Keywords: Nurseries; seedlings; eucalyptus; pests; insecticide.

\section{INTRODUCTION}

In recent years, Brazil has been gaining ground in the international market for products of forest origin. In the early 1990s, Brazil's share of world exports did not exceed $1.7 \%$. In 2000, Brazil contributed about $4 \%$ of total world exports of forest products, reflecting the growth in Brazilian exports that has taken place since the 1990s [1].

The evolution of the industrial sector to serve the most developed regions of the country resulted in the implantation of massive forests formed mostly by exotic species (originating from other countries) to meet the wood needs [2]. Among these species, the eucalyptus (Eucalyptus spp.) stands out, which has undergone a large expansion in the forest sector in recent years, due to the increase in commercial production of this species for the paper, cellulose and steel industries [3].

The consumption of eucalyptus wood in Brazil is mainly concentrated in the production of pulp and steel, consuming between $65 \%$ and $75 \%$ of the total production, with emphasis on the production of short fiber pulp, which produced around 21 million tons of pulp in the year 2020 [4].

The commercial expansion of the wood market reflected in the growth of the seedling market and, consequently, in enterprises suitable for the production and management of seedlings, characterized as forest nurseries [5].

Even though the nursery is a controlled environment, both pests and diseases, if not controlled in time, can cause economic losses even for planting in the field [3]. The defoliating beetles of the Chrysomelidae family are characterized as being the main insects that attack forest essences in Brazil, where the yellow beetle (Costalimaita ferruginea (Fabricius, 1801)) is the fourth genus recorded as harmful to eucalyptus crops, mainly in the phase of seedlings [6].

The attack of $C$. ferruginea in nurseries is characterized by its feeding preference on shoots and apical parts of seedlings, where these attacks result in their inability to develop [7]. These insects still have nocturnal habits, with the laying of their eggs being made in the ground, where the larvae feed on grass roots until they complete their cycle and the emergence of adults occurs soon after the first rains, this being the starting time. population outbreaks and consequent crop attack $[8,9]$.

In the state of Maranhão, in northeastern Brazil, the nurseries that work in the production of eucalyptus forest seedlings have problems with the incidence of $C$. ferruginea and end up using specific insecticides as a control method, usually Agritoato 400, which is applied in rotation, because when the application is made in one area, the insect migrates to another and vice versa [10].

On the other hand, there is the neem, which is a plant belonging to the Meliaceae family, known by the botanical name Azadirachta indica A. Juss. It has been used for centuries as a medicinal plant, shader, repellent, in civil 
construction, as fuel and more recently as a pesticide [11].

Thus, the present work aimed to evaluate the insecticidal effect of the aqueous extract of neem leaves on the control of $C$. ferruginea in eucalyptus.

\section{MATERIALS AND METHODS}

The experiment was carried out at the Entomology Laboratory of the Center for Agrarian Sciences (CCA) of the State University of the Tocantina Region of Maranhão (UEMASUL), in northeastern Brazil, located under geographic coordinates 531'32" $S$ and $47^{\circ} 26^{\prime} 35^{\prime \prime} \mathrm{W}$, with an average altitude of 123 meters above sea level.

\subsection{Insects and Plants}

Insects of $C$. ferruginea were collected in a high quality clonal eucalyptus seedling production nursery. It has a patio under geographic coordinates $7^{\circ} 19^{\prime} 58^{\prime \prime} \mathrm{S}$ and $47^{\circ} 28^{\prime} 08^{\prime \prime} \mathrm{W}$, with an average altitude of 148 meters above sea level.

Neem ( $A$. indica) leaves were obtained from trees present on the UEMASUL campus. The botanical identification of the material was based on morphological characters and supported by the analytical key [12]. The leaves were collected with the aid of pruning scissors and placed in paper bags until they were sent to the UEMASULEntomology Laboratory.

\subsection{Preparation of Extracts}

After collection, the leaves were dried in an oven wrapped in newspaper sheets for a period of 48 hours at $60^{\circ} \mathrm{C}$, crushed with the aid of a blender, then sieved in a $0.08 \mathrm{~mm}$ sieve, and the resulting powder weighed on a precision scale for preparing extracts (Fig. 1).

The extract was prepared from a standard concentration using $100 \mathrm{~g}$ of the crushed leaves to $900 \mathrm{~mL}$ of mineral water, leaving it to rest for 48 hours. After this permanence, filtering was done and different concentrations were prepared corresponding to the treatments, where these were constituted in concentrations of 40 , $60,80 \%$ and the control constituted only by mineral water.

\subsubsection{Effect of neem extract concentrations on Costalimaita ferruginea}

Leaves of eucalyptus seedlings were immersed in each concentration of the extract and the control in mineral water for a timed period of 30 seconds. After this time, the material was placed on a sheet of newspaper and left outdoors to dry in the shade for about 2 hours, and then transferred to Petri dishes with a diameter of 8 $\mathrm{cm}$ lined with filter paper of the same dimensions.

The collected insects were individualized in a Petri dish, with a leaf of eucalyptus seedling previously treated in the corresponding concentration being offered in each dish and, then, the dish was sealed with perforated plastic, to ensure the entry of air into the interior of the dish and prevent the escape of insects (Fig. 2).

The evaluations were carried out at $12,24,36$, $48,60,72$ and 84 hours after the experiment was set up, and the sheets were replaced in the same interval by others submitted to the same treatment and procedure described above.

\subsection{Experimental Design and Statistical Evaluation}

The experiment was conducted in a completely randomized design, consisting of four treatments (control, 40, 60 and 80\%) with ten replications. Each repetition consisted of an insect and a treated eucalyptus leaf individualized in a Petri dish, totaling 40 individuals.

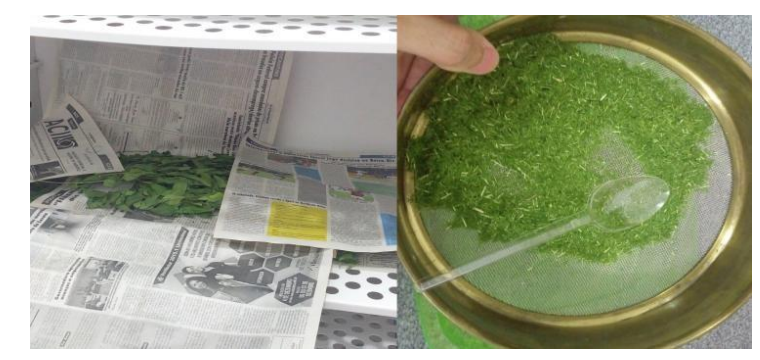

Fig. 1. Kiln dried neem leaves (left) and sieved in a $0.08 \mathrm{~mm}$ sieve (right)

Data were subjected to analysis of variance and means were compared by the Scott-Knott test at a $5 \%$ probability level, using the Assistat 7.7 program [13].

\section{RESULTS AND DISCUSSION}

Fig. 3 represents the percentage of $C$. ferruginea mortality in the evaluation intervals after the application of treatments. It is observed that the insect mortality in the evaluations of $12,60,72$ and 84 hours, there was no significant difference between treatments. In the 12-hour evaluation 
there was a variation of 20 to $50 \%$ in insect mortality, at 60 hours there was no variation with both mortality values equal to zero, at 72 hours it ranged from 0 to $20 \%$ and at 84 hours the remaining treatments reached mortality percentage of $100 \%$.

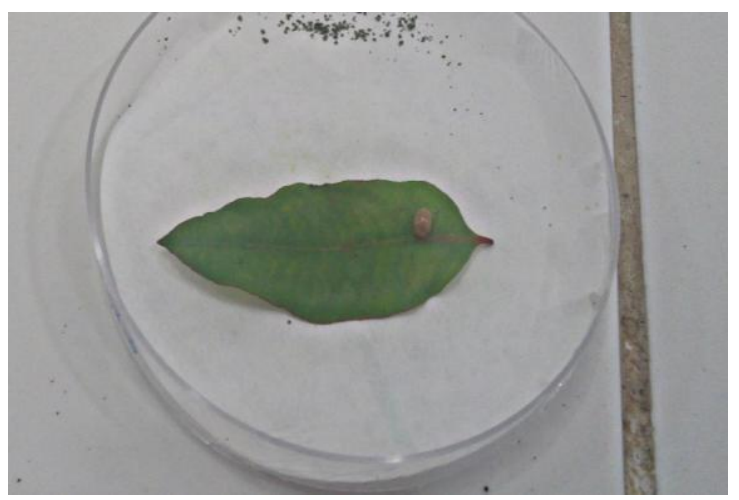

Fig. 2. C. ferruginea individualized in a Petri dish with a eucalyptus seedling leaf
previously treated at the selected
concentration

In the 24-hour evaluation, the results showed that the concentration of $60 \%$ of neem caused mortality of $50 \%$ of insects, however, it did not differ significantly from the mortality of the control treatment and $40 \%$. The $80 \%$ concentration caused lower mortality in the second evaluation, differing from the other treatments.

Thirty-six hours after the implementation of the experiment, the $60 \%$ neem concentration resulted in a mortality of $100 \%$ of the evaluated specimens, not statistically different from the $80 \%$ concentration, which resulted in a mortality of $83.3 \%$. The control and the $40 \%$ concentration provided a lower percentage of mortality, differing statistically from the higher concentrations.

Based on the above result, it is observed that the $60 \%$ neem concentration can be indicated as more effective compared to the others, as it reached the percentage of total mortality of the specimens in less time. Even though it does not differ statistically from the $80 \%$ concentration, it can be considered advantageous for presenting a similar result, with a smaller amount of extract for its preparation.

In the 48-hour evaluation, the concentration of $80 \%$ neem reached $100 \%$ mortality, statistically differing from the other treatments, especially from the control that had a mortality value equal to zero.

The result presented characterizes the effectiveness of the $80 \%$ neem concentration, proving that higher values of aqueous extract of these leaves have an insecticidal effect in the study, however compared to the 36-hour evaluation, the $60 \%$ neem concentration stands out due to the extract economy and lower time to reach the total percentage of mortality.

Similar results were found by other authors [14] who evaluated the effect of powder from dry and green neem leaves on the control of the beetle Callosobruchus maculatus (Fabricius, 1775), an important pest of the cowpea crop in its storage phase. The authors found that median dosages of dry neem powder $(1000 \mathrm{mg})$ resulted in a high adult mortality rate of $C$. maculatus.

Other authors [15] also found positive results for the use of emulsifiable neem oil on coffee fruits in the control of Hypothenemus hampei (Ferrari) (Coleoptera: Scolytidae), known as Coffee-borer. During the study, the authors reported a reduction in pierced pods when average oil concentrations (15 mg/L) were applied.

Neem has satisfactory insecticidal potential in relation to the use of its leaves and seeds. These results were confirmed by some authors [16] in the combat of Sitophilus zeamais Motsch (Coleoptera: Curculionidae), a stored grain pest. In this case, they used powder from dry leaves and seeds to combat this pest, obtaining satisfactory results for both in terms of the Repellent Index, where they ranged from 0.5 for leaves to 0.3 for seeds.

Authors [14,17] mention that the positive effect of higher concentrations of aqueous neem extract is due to Azadirachti, an active ingredient present in the leaves of this species. This bioactive is toxic to insects and, depending on the dose and time of exposure, it has a repellent effect and can affect the insect's feeding and growth.

In addition to Azadirachtin, neem leaves contain alkaloid compounds, nimbidine, tannins and resins. Such bioactive compounds are commonly used on the basis of plant pesticides, whose contents are the target of bioinsecticide combination studies [18].

During the experiment, it can be seen that mortality occurred in the control treatment, with 
an average survival of 52.8 hours (Fig. 4). A possible cause for this gradual mortality may be due to the confinement of these insects during the experiment. A certain author [9] characterizes coleoptera by the presence of elytra, which are structures that protect the wings during flight, guaranteeing the insect a specific nature of nomadism, which can be affected in its cycle when kept in captivity.

Fig. 4 represents the survival results of $C$. ferruginea fed on eucalyptus leaves treated at concentrations of 40,60 and $80 \%$ of aqueous extract of neem leaves and the control.
It is observed that the concentration that most rapidly reduced insect survival was $60 \%$ neem, with an average survival of 26.4 hours. Although this treatment presented numerically better results, statistically there was no difference between 40 and $80 \%$ treatments, differing only from the control treatment.

From the above, it can be seen that the concentration containing $60 \%$ neem, in addition to reducing survival and providing $100 \%$ faster mortality, has an advantage over the others due to the need for less raw material for the production of the extract.

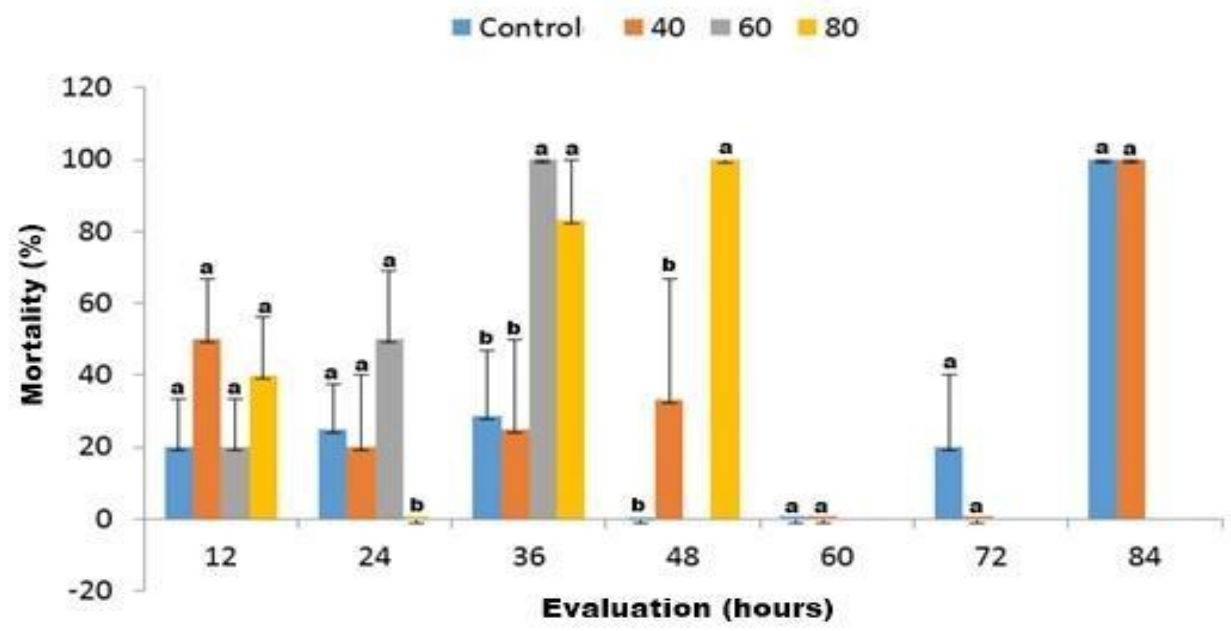

Fig. 3. Mortality of $C$. ferruginea at concentrations of 40,60 and $80 \%$ of neem leaf extract at intervals of $12,24,36,48,60,72$ and 84 hours

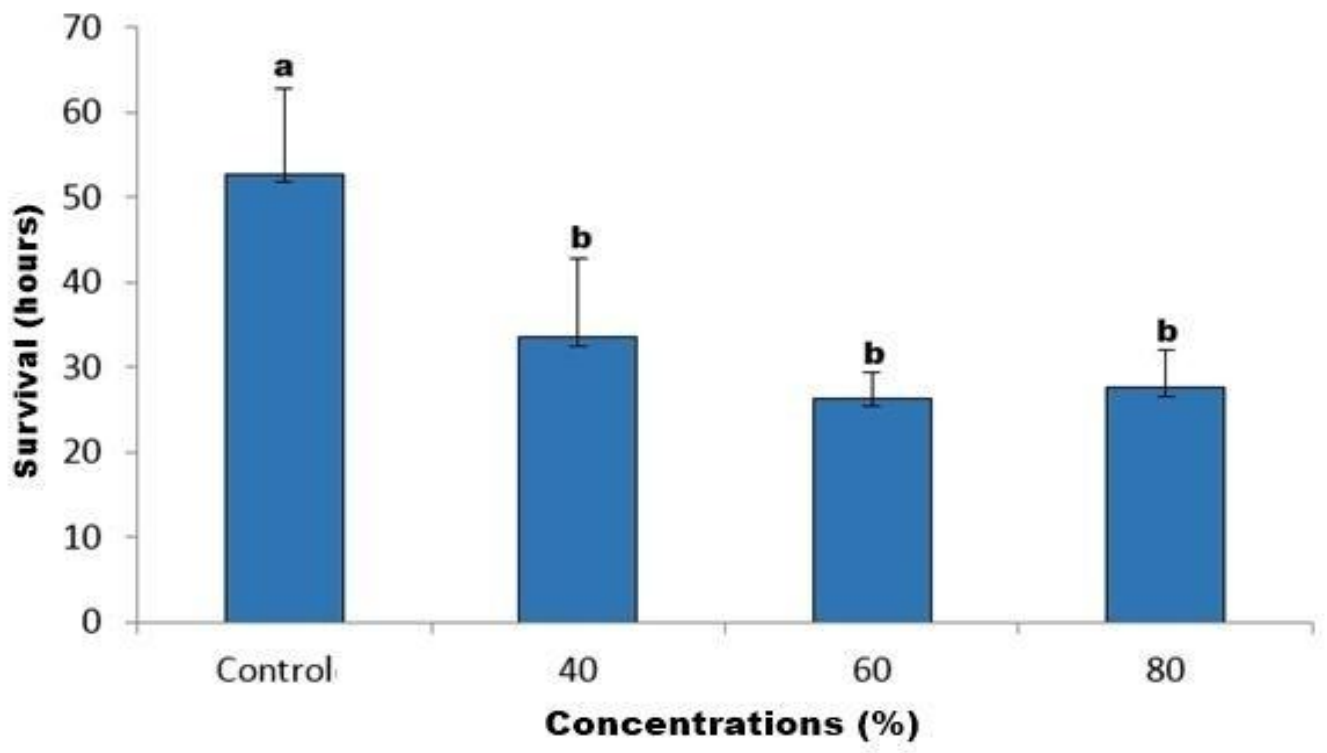

Fig. 4. Survival of $C$ ferruginea at concentrations of 40,60 and $80 \%$ 


\section{CONCLUSION}

The aqueous extract of neem leaves exerts an insecticidal effect on $C$. ferruginea.

The $60 \%$ neem concentration is the most efficient due to its rapid effect on $C$. ferruginea mortality and economy of raw material for production.

The $60 \%$ neem concentration can be an alternative to the producer as another tool to be used in Integrated Pest Management.

Further research is needed on the effect of this extract on $C$. ferruginea directly in the nursery area in order to verify the effectiveness of concentrations in normal field situations.

\section{DISCLAIMER}

The products used for this research are commonly and predominantly use products in our area of research and country. There is absolutely no conflict of interest between the authors and producers of the products because we do not intend to use these products as an avenue for any litigation but for the advancement of knowledge. Also, the research was not funded by the producing company rather it was funded by personal efforts of the authors.

\section{ACKNOWLEDGEMENTS}

The Company Marka Florestal, on behalf of Mr. Edson Luiz Marchi, for the receptivity and availability of the team to support its development.

\section{COMPETING INTERESTS}

Authors have declared that no competing interests exist.

\section{REFERENCES}

1. Susaeta A, Rossato FG. Efficiency of pulp and paper industry in the production of pulp and bioelectricity in Brazil. For Policy Econ. 2021;128:1.

Accessed 25 July 2021

DOI:https://doi.org/10.1016/j.forpol.2021.1 02484

2. Santos RC, Carneiro ACO, Castro AFM, Castro RVO, Bianche JJ, Souza MM, et al. Correlation of quality parameters of wood and charcoal of clones of eucalyptus. Sci For. 2011;39(90):221-230. Portuguese .

3. Bizi RM, Junior AG, Auer CG, Mio LLMD. Alternative products to control powdery mildew on eucalyptus seedlings. Summa Phytopathol.

Portuguese.

Accessed 25 July 2021.

DOI:https://doi.org/10.1590/S0100-

54052008000200006 .

4. Pereira LN, Pedrosa R, Oliveira EJ, Andrade D. The expansion of pulp export operations at the port of Santos. Humanidades \& Tecnologias (FINOM). Portuguese. 2021;29(1):1-9.

5. Marčiulynienè $D$, Marčiulynas $A$, Lynikienè $J$, Vaičiukynè M, Gedminas A, Menkis, A. DNA-metabarcoding of belowground fungal communities in bare-root forest nurseries: focus on different tree species. Microorganisms. 2021;9(1): 1-21.

Accessed 25 July 2021

DOI:https://doi.org/10.3390/microorganism s9010150.

6. Arnhold A, Gonçalves D. Occurrence of Costalimaita lurida (Coleoptera: Chrysomelidae) in Eucalyptus spp. in Minas Gerais state, Brazil. Pesqui Florest Bras. 2010;30(63):257-259. Portuguese.

Accessed 25 July 2021.

DOI:https://doi.org/10.4336/2010.pfb.30.63 .257.

7. Kassab SO, Mota TA, Pereira FF, Fonseca PRB. First record of Costalimaita ferruginea (Fabricius, 1801) (Coleoptera: Chrysomelidae) in eucalyptus in Mato Grosso do Sul state. Ciênc Florest. 2011;21(4):777-780.

Accessed 25 July 2021 DOI:https://doi.org/10.5902/1980509845 22

8. Montes SMNM, Sato ME, Raga A, Cerávolo LC. Evaluation of damages caused by Costalimaita ferruginea (Frabicius) (Col.: Crysomelidae) on Eucalyptus Spp. in Presidente Prudente region, São Paulo state, Brazil. Arq. Inst. Biol. Portuguese. 2012;79(3):431. 435.

9. Dias TKR, Pires EM, Souza AP, Tanaka AA, Monteiro EB, Wilcken, CF. The beetle Costalimaita ferruginea (Coleoptera: Chysomelidae) in Eucalyptus plantations in transition area of Amazon and Cerrado Biomes. Braz J Biol. Portuguese. 2018;78(1):47-52. Accessed 25 July 2021. 
DOI:https://doi.org/10.1590/15196984.03916.

10. Lima RCA, Silva FF, Freiras AS, Almeida MF, Batista MC, Tuelher ES. Register of the incidence of Costalimaita ferruginea in seedling clonal of eucalyptus in the state of Maranhão. Revista Científica Eletrônica de Engenharia Florestal. 2019; 33(1): 47-53. Portuguese.

11. Mossini SAG, Kemmelmeier C. The Neem tree (Azadirachta indica): wide-ranging uses. Acta Farm Bonaer. 2005; 24:1. Portuguese.

12. Freire CV. Analytical keys for determining the families of brazilian or exotic pteridophytes, gymnosperms and angiosperms cultivated in Brazil. 1943;3(1):1-363. Portuguese.

13. Silva FAS, Azevedo CAV. The Assistat Software Version 7.7 and its use in the analysis of experimental data. Afr J Agric Res. 2016; 11(39): 3733-3740. DOI:https://doi.org/10.5897/AJAR2016.11 522.

14. Medeiros DC, Andrade Neto RC, Figueira LK, Nery DKP, Maracajá PB, Nunes GH. Powder of dried and fresh leaves of to control in cowpea seeds. Revista Científica Eletrônica de Engenharia Florestal. 2007;6(10):1-13. Portuguese.
15. Depieri RA, Martinez SS. Reduced survival and infestation of coffee borer, Hypothenemus hampei (Ferrari) (Coleoptera: Scolytidae), on coffee fruits, in response to neem sprays in laboratory. Neotrop Entomol. 2010;39(4):632-637. DOI:https://doi.org/10.1590/S1519566X2010000400026

16. Souza MN, Vitório AC, Tanamati A, Lima AP, Lima HOS. Leaves, stems and seeds powder of neem (Azadirachta indica A. Juss.) used as repellent of Sitophilus zeamais (Coleoptera: Curculionidae) in stored corn. Braz J Food Technol Res. 2010;1(1):21-24.

DOI:https://doi.org/10.14685/rebrapa.v1i1 4.

17. Mordue AJ, Blackwell A. Azadirachtin: an update. J Insect Physiol. 1993;39(11):903- 924.

DOI:https://doi.org/10.1016/0022-

1910(93)90001-8.

18. Fauzi S, Prastowo S. Repellent Effect of the pandanus (Pandanus amaryllifolius Roxb.) and neem (Azadirachta indica) against rice weevil Sitophilus oryzae L. (Coleoptera, Curculionidae). Preprints. 2021;1:1-11.

DOI:https://doi.org/10.20944/preprints202 1 07.0123.v1.

(C) 2021 Lima et al.; This is an Open Access article distributed under the terms of the Creative Commons Attribution License (http://creativecommons.org/licenses/by/4.0), which permits unrestricted use, distribution, and reproduction in any medium, provided the original work is properly cited.

Peer-review history:

The peer review history for this paper can be accessed here: https://www.sdiarticle4.com/review-history/72571 